\title{
The costs of reducing deforestation in Indonesia
}

\author{
Colin Hunt ${ }^{1}$ \\ School of Economics, The University of Queensland \\ c.hunt3@uq.edu.au
}

Reducing tropical deforestation has taken centre stage in international efforts to curb global warming because of the large proportion of greenhouse gases released by the logging and burning of tropical forests - often for the purpose of conversion of forest lands to agricultural use. Large sums of funding have recently been pledged under the Copenhagen Accord by developed countries for reducing emissions from deforestation and forest degradation (REDD) in developing countries. This new focus on deforestation is in part due to the failure of the Copenhagen climate change conference in December 2009 to produce an agreement that would lead to coordinated global cuts in industrial, transport and household emissions. Another reason for the focus on REDD is that conventional wisdom suggests that it is cheaper to abate emissions by reducing deforestation and forest degradation in developing countries than to abate by other means in developed countries (see, for example, Boucher 2008; Busch et al. 2009; Olsen and Bishop 2008; OSIRIS 2009). As Norway’s Prime Minister put it:

By reducing deforestation, we can achieve the largest, the quickest and the cheapest cuts in global greenhouse gas emissions (Wade 2008).

There are formal markets for the carbon captured by plantation forests under the Kyoto Protocol in the Clean Development Mechanism, ${ }^{2}$ but in the absence of such markets for carbon sequestered in existing forests, REDD funds will be dispersed at the discretion of donors on a case by case basis. ${ }^{3}$

In this note I argue that the conventional wisdom is mistaken in relation to one of the most important drivers of deforestation in Indonesia: the establishment of oil palm plantations (although I also touch briefly upon another key driver - the pulp and paper industry). In assessing the costs of reducing such deforestation researchers have mostly confined their analysis to the cost of compensating palm oil companies for profits foregone: cases in point include Venter et al. (2009) and Butler et al. (2009) on the opportunity costs of stopping deforestation in Indonesia. It is argued here that methodology which concentrates exclusively on palm oil company profits (whether before or after taxes) understates the opportunity costs of REDD, and therefore sends dangerously wrong signals to potential providers of REDD funding. The inadequacy of assessing compensation costs based on agricultural profits was

\footnotetext{
${ }^{1}$ The author thanks Frank Jotzo, the editor, and other anonymous referees for helpful comments. Any errors of fact or interpretation are, however, his sole responsibility.

${ }^{2}$ For an explanation of the workings of markets for forest carbon see Hunt (2009).

${ }^{3}$ In parallel with REDD efforts is the consumer-driven need for large buyers of vegetable oils, such as Unilever, to demonstrably avoid buying palm oil from plantations that have replaced tropical forests.
} 
alluded to by Stern (2006: 610): 'This ... financial incentive would offset lost agricultural income to producers, although it would not reflect the full value chain within the country'(emphasis added).

Also overlooked in the literature is the challenge of devising REDD development schemes in regional areas that are politically acceptable to the relevant governments and that come anywhere near to matching the full economic benefits of foregone palm oil (or pulp) production. Such schemes could take years to formulate and implement. The costs of REDD are increased by the high investment costs necessitated by lengthy planning processes.

Indonesia is one the largest emitters of greenhouse gases, mainly as a result of land use change. It is therefore a key target country in terms of investment of REDD funds, and it will need these funds to reduce its greenhouse gas emissions by $26 \%$ by 2020 - a formal undertaking made as a follow-on from the Copenhagen Accord (UNFCCC 2010). The major agreement with Norway to protect Indonesia's forests and peatlands signed in Oslo in May 2010, under which Indonesia could receive up to $\$ 1$ billion in grants (ANTARA News, 27/5/2010), is indicative of the potential for such investments.

The potential for reducing emissions by 2020 lies substantially in a reduction in the rate of deforestation. Along with timber production and pulp and paper manufacture, the palm oil industry is a major source of emissions through forest clearing and the conversion to plantations. Palm oil is highly profitable, and the contribution of Indonesia's 320 palm oil producers to Gross Domestic Product (GDP) increased by an estimated annual average of 18\% during 2003-05 (Tambunan 2006: 4). Up until now, $70 \%$ of oil palm plantations have replaced forest (IFCA:30) - the timber income generated by forest clearing offsetting the cost of plantation establishment. In Kalimantan, oil palm permits have been issued in recent years for 1.7 million hectares of forest - including 0.5 million hectares of peat lands, which have a high carbon content (IFCA 2007: 31). Expansion is likely to continue at around 5,500 $\mathrm{km}^{2}$ a year, but it is unclear how much forested land has been allocated to oil palm by provincial governments. Knowing this is crucial to estimating the emissions from forestry, because the central government will not be revoking existing forestry concessions and licences as a result of the new agreement with Norway, but will simply put a two year moratorium on new concessions (Koswanage 2010).

As well as being profitable to both private and government-owned palm oil companies, there are also substantial benefits to other parties, most obviously smallholders. These include both 'outgrowers' (plasma) (numbering at least 400,000) linked to the palm oil companies (inti), and independent individual growers, who also number in the hundreds of thousands. These smallholder groups harvest fresh fruit from some two million hectares, contributing a third of total palm oil production.

Moreover, the companies themselves employ over a million workers in the plantations and processing mills, as well as in the ongoing conversion of forests to plantations and in the construction of new mills (Zen et al. 2005). ${ }^{4}$

${ }^{4}$ Smallholder involvement will not be as important in the future, however, given that recent oil palm legislation has drastically reduced the smallholder component of plantations in favour of company-dominated concessions where companies can own outright up to $80 \%$ of the plantation. 
As well as palm oil companies, outgrowers and workers directly involved, governments - and therefore the wider Indonesian public - are also major beneficiaries from the expansion of the palm oil industry. All palm oil companies pay export tax, income tax and value-added tax, while the individuals employed by them also pay income tax. In addition, the national, provincial and district governments benefit financially from issuing permits and collecting land taxes and lease payments on land used for oil palm. ${ }^{5}$ In short, the oil palm industry is large and profitable, and capable of generating significant revenue in a variety of forms to governments at all levels.

But the economic impact of the palm oil industry is also important by virtue of the involvement of firms that supply it with goods and services of all kinds. Expenditure is necessary for inputs such as fertilisers, fuel, plant and equipment, maintenance of road networks, plantations and mills, collecting the oil palm fruit, and the domestic distribution or export of the palm oil produced. Part of the cash flow to the suppliers of these goods and services is spent on additional goods and services from other suppliers, and so on. An examination of randomly chosen Indonesian palm oil company annual accounts suggests that for every dollar of net profit made by palm oil companies, about three dollars are contributed to national income through direct and indirect spending on supplies of goods and services and labour (Lestari 2008; Lonsom 2008; SMART 2008).

To summarise: the true opportunity costs of REDD include the future after-tax profits of palm oil companies and smallholders, together with government tax revenues, and to this must be added the impact on the economy at large resulting from reduced spending by these companies and smallholders on supplies of goods and services. Similar comments apply to the logging companies and pulp mills that also operate under permits and leases in government-owned forests. As in the case of palm oil, the opportunity cost of cessation of pulp mill expansion would include not just the net profits of the companies involved but also the economic impact on downstream processing and local employment generation (Pirard 2008). Note also that timber, pulp and palm oil operations are all widely dispersed geographically, thus providing highly decentralised business and employment opportunities that would otherwise be hard to replicate.

Regulations already in place allocate the proceeds of the sale of carbon credits from conserved forest that would otherwise be logged and/or converted to agriculture to the three tiers of government, the local community and the holders of permits to clear the forest (Government of Indonesia 2009). ${ }^{6}$ Given that the issue of new permits for conversion of forest to agricultural use appears no longer possible under the agreement with Norway, a real challenge will be the deployment of carbon credits by the stakeholders in a way that matches foregone income generation from palm oil and other land uses. Moreover, a coordinated approach to the investment of carbon funds will probably prove very

\footnotetext{
${ }^{5}$ While local governments benefit substantially from oil palm developments, local officials may at the same time be nervous about the impact on local communities of the consequential immigration (Sandker et al. 2007). ${ }^{6}$ This arrangement was presumably framed in the anticipation that a market would evolve for carbon credits derived from REDD. However, the situation now is that bilateral or multinational donors, rather than the market, will be the source of direct carbon payments to government.
} 
difficult, given the high degree of autonomy that provincial and local governments now enjoy in determining land use and economic development within their own borders.

For REDD initiatives to be effective, a national approach to curbing the establishment of new palm oil plantations is essential. There is a danger that avoiding the establishment of a new plantation in one region might simply result in its relocation to another region - or indeed to another country, such as neighbouring Papua New Guinea (PNG) or elsewhere in the Pacific region - in which case the impact of REDD on emissions reduction would be undermined. The pressure on palm oil companies to relocate offshore will depend on how much already-cleared land is suitable for the establishment of plantations, which is very unclear at present. While it has been suggested that 6 million hectares of degraded land is available across the archipelago (Koswanage 2010), its use might well be subject to competing claims.

For a REDD scheme to be effective in reducing emissions, very tight rules would need to be applied to the flows of billions of dollars through government agencies. While it is likely that donors will advance compensation only after it has been demonstrated that deforestation has actually been reduced, it is open to question whether REDD donors will trust the government to apply the funds as intended without strict oversight. Any leakage of funds from the compensation packages would further increase the unit costs of greenhouse emissions avoided. On the other hand, maintaining sovereignty is important to Indonesia. It is therefore likely that the government would want to exert a high degree of control over REDD funds rather than allowing the donor countries to determine the allocation of compensation.

REDD donor governments are answerable to their electorates and so will want a demonstrable 'bang for their buck'. Donors would thus need to be kept continually informed, not only of the amount and security of the carbon sequestered in the now conserved forests, but also of the progress of the particular compensatory packages in averting economic losses and contributing to sustainable regional development. A question that looms large in the case of the new agreement with Norway is: what will happen after the two year moratorium on the issue of new forestry concessions expires?

Boucher, D., 2008. Out of the woods: A realistic role for tropical forests in curbing global warming, Union of Concerned Scientists, UCS Publications, Cambridge, MA.

Government of Indonesia, 2009. Regulation of the Minister of Forests concerning administrative arrangements for licensing, benefiting, absorbing and/or sequestering carbon in production forests and conservation forests, Nomor: P.36/Menhut-II/2009.

Hunt, C., 2009. Carbon sinks and climate change: forests in the fight against global warming, Edward Elgar, Cheltenham, UK. 
IFCA (Indonesia Forest Climate Alliance), 2007. Reducing emissions from deforestation and forest degradation in Indonesia, Indonesia Forest Climate Alliance, Jakarta.

Koswanage, Niluksi 2010. 'Indonesia says won't revoke existing forestry licenses', Reuters, June 2

Olsen, N. and Bishop, J., 2008. The financial costs of REDD, IUCN/Rio Tinto, IUCN Gland, Switzerland.

OSIRIS, 2009. Supporting the REDD Options Assessment Report to the Government of Norway, at: http://www.conservation.org/osiris/Pages/overview.aspx

Pirard, R., 2008. Estimating opportunity costs of avoided deforestation (REDD): application of a stepwise approach to the Indonesian pulp sector, International Forestry Review, 19(3): 512-522.

PT Astra Agro Lestari Tbk, 2008. 2007 Annual Report, at: http://www.astraagro.co.id/index.php/ourcompany

PT PP London Sumatra Indonesia Tbk, 2008. Lonsum FY 2007 Annual Report, at: http://www.londonsumatra.com/default.asp

PT Smart Tbk, 2008. Annual Report Year of 2007, at: http://www.smart-tbk.com/ Comment [RHM1]: needs to be more precise.

Sandker, M., Suwarno, A. and Campbell, B., 2007. 'Will forests remain in the face of oil palm expansion? Simulating change in Malinau, Indonesia', Ecology and Society 12(2): 37, at:

http://www.ecologyandsociety.org/vol12/iss2/art37/

Stern, N., 2006. The economics of climate change, Cambridge University Press, Cambridge.

Tambunan, Tulus T., 2006. Indonesian crude palm oil: production, export performance and competitiveness, Kadin-Jetro, September, at: http://www.kadin-

indonesia.or.id/en/doc/opini/Indonesian Crude Palm Oil Production Export Performance And C ompetitiveness.pdf

UNFCCC (United Nations Framework Convention on Climate Change), 2010. Nationally appropriate mitigation actions, Letter to the Executive Secretary, UNCCC, from the National Council on Climate Change, Jakarta, at:

http://unfccc.int/files/meetings/application/pdf/indonesiacphaccord_app2.pdf

Wade, Gabrielle 2008. 'Reducing deforestation important to cutting carbon emissions', MEDIAGLOBAL, 28 September, at: http://www.mediaglobal.org/article/2008-09-28/reducingdeforestation-important-to-cutting-carbon-emissions Zen, Z., Barlow C. and Gondowarsito, R., 2005. Oil palm in Indonesian socio-economic improvement: a review of options, Research School of Pacific and Asian Studies, Australian National University, at:

http://rspas.anu.edu.au/economics/publish/papers/wp2005/wp-econ-2005-11.pdf 
